\title{
Meningkatkan Kemampuan Mahasiswa Dalam Membuat RPP Melalui Penerapan Model Pembelajaran Project Based Learning
}

\section{Mproving Students 'Capabilities In Making RPP Through The Application Of Learning Based Learning Models}

\author{
Adi Nurjaman ${ }^{1}$, Ratni Purwasih ${ }^{2 *}$, Indah Puspita Sari ${ }^{3}$ \\ ${ }^{1}$ Prodi Pendidikan Matematika, STKIP Siliwangi \\ * Korespondensi Penulis. E-mail: ratnipurwasih61@gmail.com, Telp: +6281809610161
}

Keywords:

Project based learning

Eksperimen

Pembelajaran Matematika

\begin{abstract}
Penelitian ini bertujuan untuk mengetahui respon mahasiswa terhadap penerapan model pembelajaran project based learning untuk mengetahui peningkatan kemampuan mahasiswa dalam menyusun RPP melalui penerapan model pembelajaran project based learning serta respon mahasiswa dalam pembelajaran project based learning antara kelas eksperimen dan kelas kontrol. Metode penelitian ini adalah metode kuasi eksperimen dengan desain penelitian pretset-posttest control group design. Populasi penelitian adalah seluruh mahasiswa STKIP Siliwangi yang mengikuti mata kuliah Perencanaan Pembelajaran Matematika sekolah menengah pada semester genap Tahun Ajaran 2016/2017 yang terdiri dari 3 kelas, yaitu: B1, B2, dan B3. Untuk sampel penelitian dipilih 2 kelas dari populasi penelitian, terpilih kelas B1 sebagai kelas kontrol yang terdiri dari 40 orang mahasiswa dan kelas B2 sebagai kelas eksperimen yang terdiri dari 43 orang mahasiswa. Sampel dipilih tidak acak kelas. Analisis data dilakukan terhadap perbedaan rerata hasil tes kemampuan mahasiswa dalam menyusun RPP dan presentase dari angket respon mahasiswa terhadap pembelajaran project based learning . Hasil penelitian menunjukkan bahwa sebagian besar mahasiswa memberikan respon positif terhadap penerapan model pembelajaran project based learning dengan rata-rata persentase pretes dan postes kelas eksperimen masingmasing sebesar $67,49 \%$ dan 77,09\% termasuk katagori kuat. Sedangkan dengan rata-rata persentase pretes dan postes kelas kontrol masingmasing sebesar $61,50 \%$ dan $63,97 \%$ katagori sedang. Peningkatan kemampuan mahasiswa dalam menyusun RPP melalui penerapan model pembelajaran project based learning rerata gainnya sebesar 0,57 kelas eksperimen termasuk dalam kategori sedangkan kelas kontrol sebesar 0,36 kategori sedang; dan peningkatan kemampuan mahasiswa dalam menyusun RPP yang memperoleh penerapan model pembelajaran project based learning lebih tinggi daripada yang memperoleh penerapan model pembelajaran konvensional.
\end{abstract}

Copyright (C) 2018 Universitas Mercu Buana Yogyakarta. All rights reserved.

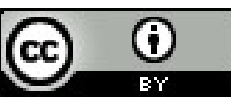

$\mathrm{W}:$ http://ejurnal.mercubuana-yogya.ac.id/index.php/mercumatika

E : mercumatika@mercubuana-yogya.ac.id 
Keywords:

Project based learning

Experiment

Learning Mathematics

\begin{abstract}
This study aims to determine the response of students to the implementation of learning-based project learning model to determine the student's ability to develop RPP through the application of learning-based project learning model and student response in project based learning learning between experimental class and control class. This research method is quasi experimental method with pretset-posttest control group design design. The study population is all students of STKIP Siliwangi who follow the course of High School Mathematics Learning Planning in the even semester of the academic year 2016/2017 consisting of 3 classes, namely: B1, B2, and B3. For the sample of the study, two classes were selected from the study population, selected B1 class as a control class consisting of 40 students and B2 class as experimental class consisting of 43 students. The sample is selected not random class. Data analysis was done to the difference of mean of student ability test result in preparing RPP and percentage from questionnaire of student response to learning of project based learning. The results showed that most of the students gave positive responses to the application of learning-based learning model with average of pretest and posttest class percentage of experiment respectively $67,49 \%$ and $77,09 \%$ including strong category. Meanwhile, the average of pretest and posttest percentage of control class were $61.50 \%$ and $63.97 \%$, respectively. Improvement of students ability in preparing RPP through the implementation of learning model project based learning average gain of 0.57 experimental class included in the category while the control class of 0.36 medium category; And the improvement of the students' ability in preparing the lesson plan that obtained the application of project based learning model is higher than that obtained the application of conventional learning model.
\end{abstract}

Copyright $(2018$ Universitas Mercu Buana Yogyakarta. All rights reserved.

\title{
PENDAHULUAN
}

Pada jenjang pendidikan tinggi, mahasiswa dituntut memiliki kemampuan kognitif tingkat tinggi, seperti analisis, sintesis atau aplikasi berbagai berbagai formula (Kurniasih, 2017:752). Mahasiswa diharapkan mampu untuk bernalar dengan baik dan mengekspresikan hasil penalarannya secara tertulis, sistematis dan logis. Kemampuan ini dapat diperoleh salah satu nya melalui proses perencanaan pembelajaran yang baik. Untuk tercapainya tujuan pendidikan nasional maka diperlukan peran guru sebagai perantara dalam proses pembelajaran. Guru berperan penting dalam mendidik siswa di sekolah. Sebagai tenaga pendidik peran guru mengajarkan berbagai pelajaran, memberi nasehat agar siswa memiliki kepribadian baik sesuai karakter bangsa (Putri \& Agustyaningrum, 2017: 98). Guru memiliki peran penting pada saat pembelajaran berlangsung. Kemampuan guru mengelola kelas dan menyiapkan skenerio pembelajaran unsur utama sebelum memasuki kelas. Kemampuan dan kemahiran menyusun rencana pembelajaran yang akan disamapaikan kepada siswa membantu tercapai secara optimal tujuan dari pembelajaran yang diharapkan .

Sekolah merupakan salah satu pendidikan formal yang diwajibkan untuk seluruh anak bangsa indonesia. Dalam proses pendidikan meliputi unsur pendidik dan peserta didik. Pendidikan di sekolah di lakukan melalui proses pembelajaran di kelas. Dalam proses pembelajaran ada tujuantujuan yang harus dicapai. Tujuan pembelajaran bisa tercapai dengan baik bila proses pembelajaran direncanakan dengan baik pula. Rencana yang dibuat pendidik untuk melaksanakan proses kegiatan pembelajaran di kelas dituangkan dalam bentuk Rencana Pelaksanaan Pembelajaran (Izzati, 2017:660). Guru yang lebih siap untuk memasuki ruangan kelas berdampak terhadap siswa. Baik dari prestasi siswa, motivasi dan kepahaman siswa terhadap materi pelajaran yang disampaikan guru tersebut. Guru yang memiliki kemampuan menguasai kelas dan materi ajar akan berdampak terhadap motivasi belajar siswa. Hal ini sebagaimana Nurmahmidah (2017:140) mengatkan bahwa penting dan perlu diketahui oleh setiap guru dalam peranannya yaitu dapat menumbuhkan gairah, merasa senang dan semangat belajar bagi siswa. Menurut Winkel (2004: 169), motivasi belajar 
adalah keseluruhan daya penggerak psikis dalam diri siswa yang menimbulkan kegiatan belajar, menjamin kelangsungan kegiatan belajar itu demi mencapai suatu tujuan.

Salah satu kampus yang mencetak calon guru yang smart dan inovatif adalah STKIP Siliwangi Bandung. Mahasiswa jurusan pendidikan matematika harus mampu memiliki kemampuan yang baik dalam menyusun RPP untuk diaplikasikan pada saat mereka mengajar di kelas. Perencanaan Pembelajaran Matematika sebagai salah satu mata kuliah yang mempelajari cara menyusun RPP. Dalam mata kuliah ini diajarkan cara menyusun RPP yang baik, mulai dari menganalisa kemampuan awal peserta didik, menentukan alokasi waktu, menentukan indikator, media, bahan ajar sampai membuat instrumen yang tepat untuk mengukur ketercapaian tujuan pembelajaran. RPP yang di bahas dalam mata kuliah perencanaan pembelajaran matematika sekolah menengah adalah RPP untuk sekiolah menengah pertama dan sekolah menengah atas. Melalui penyusunan RPP ini mahasiswa mampu menyusun berbagai tahap-tahap pembelajaran inovatif yang diterapkan pada saat pembelajaran berlangsung.

Tujuan dari mata kuliah perencanaan pembelajaran matematika menengah adalah membekali mahasiswa calon guru mempunyai kemampuan menyusun RPP sebaik mungkin agar proses kegiatan belajar dan mengajar di kelas berhasil. RPP merupakan skenerio pembelajaran yang wajib para pendidik susun secara matang agar pembelajaran berjalan baik dan tujuan dari pembelajaran dapat tercapai sesuai harapan. Penyusunan RPP dengan baik akan memberikan dampak yang baik sebaliknya penyusunan RPP yang kurang membuat pelaksanaan pembelajaran tidak berhasil secara optimal. Tercapai atau tidaknya suatu tujuan berdasarkan baik atau tidaknya perencanaan yang dibuat.

Meningkatkan kemampuan mahasiswa dalam menyusun RPP merupakan landasan utama kompetensi yang harus dimiliki mahasiswa calon guru. Oleh karena itu, perlu suatu upaya untuk meningkatkan kemampuan mahasiswa dalam penyusunan RPP agar mereka mampu memberikan pembelajaran yang terbaik pada saat menyampaikan materi di depan siswa. Salah satunya adalah penerapan model pembelajaran project based learning pada mata kuliah Perencanaan Pembelajaran Matematika sekolah menengah. Thomas (Putra \& Purwasih, 2015: 129) mengungkapkan bahwa model pembelajaran project based learning merupakan sebuah pembelajaran inovatif yang lebih menekankan pada pendekatan kontekstual melalui kegiatan-kegiatan yang kompleks, melibatkan mahasiswa dalam melakukan investigasi pemecahan masalah dan kegiatan bermakna, memberi kesempatan bekerja secara mandiri dalam mengkonstruksi pengetahuan, serta menghasilkan produk nyata.

Model pembelajaran yang melibatkan mahasiswa secara aktif. Mahasiswa tidak hanya mempelajari cara menyusun RPP yang baik secara teori, tetapi mereka juga harus langsung mempraktekkan cara menyusun RPP dan mengumpulkannya dalam bentuk makalah. Dengan langsung mempraktekkan cara menyusun RPP diharapkan mahasiswa langsung memahami cara menyusun RPP, sehingga kemampuan mahasiswa dalam menyusun RPP juga meningkat.

Model pembelajaran project based learning dapat membantu keaktifan mahasiswa dalam pembelajaran. Model ini juga sesuai untuk diterapkan pada mata kuliah perencanaan pembelajaran matematika menengah, karena mahasiswa diminta untuk menyusun RPP dan mereka mempraktekan RPP tersebut ke sekolah formal untuk latihan. Setiap pertemuan perkuliahan, mahasiswa ditugaskan untuk berlatih membuat RPP kemudian pada saat perkuliahan, mereka di intruksikan untuk mencoba mempraktekan di kelas secara berkelompok. Untuk kelompok yang sudah bagus RPP nya, mereka ditugaskan ke sekolah formal untuk praktek secara langsung dihadapan siswa. Hal ini salah satu bentuk latihan mahasiswa agar terbiasa dan terlatih mengajar sesuai dengan RPP yang mereka susun sebelumnya. Berdasarkan pemaparan di atas, maka diharapkan penerapan model pembelajaran project based learning dapat meningkatkan kemampuan mahasiswa dalam menyusun RPP. 
Vol. 2, No. 2, April 2018, pp. 33-42

Berdasarkan latar belakang yang telah diuraikan, rumusan masalah dalam penelitian ini adalah:

1. Bagaimana respon mahasiswa terhadap penerapan model pembelajaran project based learning?

2. Bagaimana peningkatan kemampuan mahasiswa dalam menyusun RPP melalui penerapan model pembelajaran project based learning?

3. Apakah terdapat perbedaan peningkatan kemampuan mahasiswa dalam menyusun RPP antara yang memperoleh penerapan model pembelajaran project based learning dengan yang memperoleh penerapan model pembelajaran konvensional?

Berdasarkan perumusan masalah, tujuan penelitian ini adalah:

1. Mengetahui respon mahasiswa terhadap penerapan model pembelajaran project based learning?

2. Mengetahui peningkatan kemampuan mahasiswa dalam menyusun RPP melalui penerapan model pembelajaran project based learning?

3. Mengetahui perbedaan peningkatan kemampuan mahasiswa dalam menyusun RPP antara yang memperoleh penerapan model pembelajaran project based learning dengan yang memperoleh penerapan model pembelajaran konvensional?

Adapun hipotesis dalam penelitian ini adalah: peningkatan kemampuan mahasiswa dalam menyusun RPP yang memperoleh penerapan model pembelajaran project based learning lebih tinggi daripada yang memperoleh penerapan model pembelajaran konvensional

\section{Project Based Learning}

Model pembelajaran berbasis proyek (project based learning)memiliki lima langkah pembelajaran Marlinda (Harry \& Purwasih 2015:131), yaitu: (1) menentukan tema proyek. dalam penyusunan RPP ini tema proyek yang mahasiswa susun meliputi komponen-komponen RPP yang di sesuaikan dengan metode atau strategi pembelajaran yang akan mereka ajarkan.

Tema proyek hendaknya memenuhi indikator, sebagai berikut: a) memuat gagasan umum dan orisinil; b) penting dan menarik; c) mendeskripsikan masalah kompleks; dan d) mencerminkan hubungan berbagai gagasan. Pada langkah pertama ini, yang lebih berperan adalah dosen sebagai fasilitator untuk menetapkan tema yang akan dipelajari mahasiswa selama proses pembelajaran; (2) menetapkan konteks belajar. Konteks belajar hendaknya memenuhi indikator-indikator, sebagai berikut: a) pertanyaan-pertanyaan proyek mempersoalkan masalah dunia nyata;b) mengutamakan otonomi mahasiswa; c) melakukan inquiry dalam konteks masyarakat; d) mahasiswa mampu mengelola waktu secara efektif dan efisien; e) mahasiswa belajar penuh dengan kontrol diri; dan f) mensimulasikan kerja secara profesional.

Tahap ini mahasiswa di tuntut untuk mampu menggali kemampuannya dalam menyusun RPP dan bekerja secara kolaboratif; (3) merencanakan aktivitas-aktivitas. Pengalaman belajar terkait dengan merencanakan proyek, sebagai berikut: a) membaca; b) meneliti; c) observasi; d) interviu; e) merekam; f) mengunjungi objek yang berkaitan dengan proyek; dan g) akses internet.

Pada tahap ketiga ini, mahasiswa yang telah memperoleh tema berkesempatan menyusun dan melaksanakan tema proyek dalam komponen-komponen penyusunan RPP; (4) Memproses aktivitas-aktivitas. Indikator-indikator memproses aktivitas, sebagai berikut: a) membuat sketsa; b) melukiskan analisa; c) menghitung; dan 4) mengembangkan prototipe. Langkah ini memberikan kontribusi terhadap kinerja ilmiah, sebab dalam langkah ini indikator pertama kinerja ilmiah, yaitu merencanakan dan merancang. Perencanaan yang dilakukan mahasiswa sejalan pada tahap ketiga, 
hanya saja pada tahapan ini perencanaan lebih dibuat khusus, seperti pembuatan langkah-langkah praktek mengajar yang sesuai dengan inti pembelajaran yang ada dalam RPP. Untuk tahap merancang, dilakukan pada saat praktikum, yaitu pada saat penyusunan RPP; (5)Penerapan aktivitas-aktivitas untuk menyelesaikan proyek. Langkah-langkah yang dilakukan, antara lain: a) mencoba mengerjakan proyek berdasarkan sketsa; b) menguji langkah-langkah yang telah dikerjakan dan hasil yang diperoleh; c) mengevaluasi hasil yang telah diperoleh; d) merevisi hasil yang telah diperoleh;e) melakukan daur ulang proyek yang lain; dan f) mengklasifikasi hasil terbaik. Langkah kelima memberikan kontribusi pada kinerja ilmiah, yaitu menggunakan peralatan, pelaksanaan pengukuran, observasi dan pencatatan data, interpretasi dan tanggung jawab

\section{Metode}

Metode dalam penelitian ini adalah metode kuasi eksperimen. Pada kuasi eksperimen ini subjek tidak dipilih secara acak, tetapi peneliti menerima keadaan subjek seadanya (Ruseffendi, 2010). Dalam penelitian ini ada pemanipulasian perlakuan, dimana kelas yang satu mendapatkan pembelajaran menggunakan project based learning sedangkan kelas lain mendapat pembelajaran menggunakan pembelajaran konvensional. Pada awal dan akhir pembelajaran kedua kelas diberi tes sehingga desain penelitiannya menurut (Ruseffendi, 2010: 50) adalah sebagai berikut :

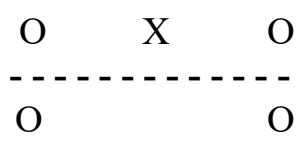

Keterangan :

O : Tes kemampuan mahasiswa dalam menyusun RPP (prestes dan postes)

$\mathrm{X} \quad$ : model pembelajaran project based learning

- - - - - : Pengambilan sampel tidak acak kelas

Populasi penelitian adalah seluruh mahasiswa jurusan pendidikan matematika pada semester genap tahun akademik 2016/2017 pada mata kuliah Perencanaan Pembelajaran Matematika sekolah menengah sebanyak 3 kelas yaitu kelas B1, B2 dan B3. sampel penelitian diambil secara tidak acak. kelas B1 sebagai kelas kontrol yang terdiri dari 40 orang mahasiswa dan kelas B2 sebagai kelas eksperimen yang terdiri dari 43 orang mahasiswa. Kelas eksperimen memperoleh penerapan model pembelajaran project based learning dan kelas kontrol memperoleh penerapan model pembelajaran konvensional.

Instrumen yang di gunakan dalam penelitian adalah tes kemampuan menyusun RPP (Pretes dan Postes) dalam bentuk essay dan angket respon mahasiswa penerapan model pembelajaran project based learning yang terdiri dari 20 butir pernyataan menggunakan skala likert termodifikasi dengan lima pilihan jawaban, yaitu: sangat setuju (SS), setuju (S), tidak setuju (TS), sangat tidak setuju (STS). Kelompok favourable terdiri dari pertanyaan-pertanyaan yang bersifat positif atau mendukung objek sikap (Sariningsih \& Purwasih, 2017). Sedangkan kelompok item unfavourable terdiri dari pertanyaan-pertanyaan negatif atau tidak mendukung objek sikap. Format skoring skala angket respon mahasiswa terhadap pembelajaran project based learning disajikan pada Tabel 1 berikut:

Tabel 1. Format Skoring Skala Angket Respon Mahasiswa dalam Penyusunan RPP

\begin{tabular}{ccc}
\hline Pilihan jawaban & Favourable (Positif) & Unfavourable (Negatif) \\
\hline SS & 4 & 1 \\
S & 3 & 2 \\
TS & 2 & 3 \\
STS & 1 & 4 \\
\hline
\end{tabular}


Vol. 2, No. 2, April 2018, pp. 33-42

Data yang diperoleh dari hasil tes diolah melalui tahap-tahap yaitu jawaban pretes dan postes diperiksa dan diberikan skor sesuai tabel penskoran, mengolah data gain untuk melihat peningkatan kemampuan mahasiswa menyusun RPP, menguji perbedaan antara dua rerata data gain, dalam hal ini antara data gain kelas eksperimen dan data gain kelas kontrol. Uji statistik yang digunakan adalah uji-t. Semua pengolahan data menggunakan bantuan software SPSS 17.0 dan microsoft excel 2010.

\section{Hasil Penelitian dan Pembahansan}

Untuk mengetahui respon mahasiswa terhadap penerapan model pembelajaran project based learning, diberikan angket yang berisi 20 butir pernyataan dengan lima pilihan jawaban, yaitu sangat setuju (SS), setuju (S), tidak setuju (TS), sangat tidak setuju (STS) kepada 33 orang mahasiswa kelas eksperimen. Hasil dari penyebaran angket respon mahasiswa terhadap penerapan model pembelajaran berbasis portofolio diolah dengan menggunakan program SPSS 17.0, diperoleh deskripsi data respon mahasiswa dengan kriteria prosentase skor hasil angket motivasi belajar siswa akan dianalisis sesuai dengan kriteria yang diadaptasi dari pedoman penilaian (Riduwan, 2007: 15):

\section{Tabel 2. Skoring Skala Angket Respon Mahasiswa Terhadap Pembelajaran Project Based} Learning

\begin{tabular}{ll}
\hline Kriteria & Klasifikasi \\
\hline $0 \leq \mathrm{NA} \leq 20$ & Sangat Lemah \\
$20<\mathrm{NA} \leq 40$ & Lemah \\
$40<\mathrm{NA} \leq 60$ & Cukup \\
$60<\mathrm{NA} \leq 80$ & Kuat \\
$80<\mathrm{NA} \leq 100$ & Sangat Kuat \\
\hline
\end{tabular}

Selanjutnya dilakukan analisis data angket respon mahasiswa menggunakan software Microsoft Office Excel 2010 untuk mengetahui apakah angket respon mahasiswa yang pembelajarannya menggunakan pendekatan project based learning lebih baik daripada yang pembelajarannya menggunakan pembelajaran konvensional.

Tabel 3. Deskriptif Statistik Pretes Angket Respon MahasiswaKelas Kontrol

\begin{tabular}{lcc}
\hline \multicolumn{1}{c}{ Indikator } & Pretes & Postes \\
\hline Menunjukkan rasa yakin dengan kemampuan yang dimiliki. & $55,41 \%$ & $57,67 \%$ \\
Menunjukkan kemandirian dalam mengambil keputusan. & $59,63 \%$ & $63,56 \%$ \\
Memiliki kecerdasan (kemampuan matematika) yang cukup. & $54,38 \%$ & $58,56 \%$ \\
$\begin{array}{l}\text { Menunjukkan rasa optimis, dan keberanian dalam mengambil } \\
\text { keputusan. }\end{array}$ & $65,78 \%$ & $63,06 \%$ \\
$\begin{array}{l}\text { Memiliki kemampuan sosialisasi. } \\
\text { Menunjukkan sikap positif dalam pembelajaran project based }\end{array}$ & $54,06 \%$ & $58,37 \%$ \\
learning & $59,19 \%$ \\
$\begin{array}{l}\text { Mampu menyesuaikan diri dan berkomunikasi dalam } \\
\text { kelompok diskusi. }\end{array}$ & $55,21 \%$ & $58,17 \%$ \\
\hline
\end{tabular}

Adi Nurjaman et.al (Meningkatkan Kemampuan Mahasiswa Dalam Membuat RPP Melalui Penerapan Model Pembelajaran Project Based Learning) 


\begin{tabular}{lcc}
\hline Memiliki kemampuan untuk menyusun kalimat secara baik. & $77,5 \%$ & $73,17 \%$ \\
Total & $61,50 \%$ & $63,97 \%$ \\
\hline
\end{tabular}

Tabel 4. Deskriptif Statistik Pretes Angket Respon Mahasiswa Kelas Eksperimen

\section{Indikator}

Menunjukkan rasa yakin dengan kemampuan yang dimiliki.

Menunjukkan kemandirian dalam mengambil keputusan.

Memiliki kecerdasan (kemampuan matematika) yang cukup.

Menunjukkan rasa optimis, dan keberanian dalam mengambil keputusan.

Memiliki kemampuan sosialisasi.

Menunjukkan sikap positif dalam pembelajaran project based learning

Mampu menyesuaikan diri dan berkomunikasi dalam kelompok diskusi.

Memiliki kemampuan untuk menyusun kalimat secara baik.

Total

$\begin{array}{cc}\text { Pretes } & \text { Postes } \\ 59,69 \% & 75,51 \% \\ 64,69 \% & 71,25 \% \\ 58,84 \% & 75,53 \% \\ 71,47 \% & 77,29 \% \\ & \\ 78,50 \% & 82,54 \% \\ 63,37 \% & 78,42 \% \\ & \\ 65,17 \% & 77,52 \% \\ & \\ 78,17 \% & 83,58 \% \\ 67,49 \% & 77,09 \%\end{array}$

Hasil analisis penelitian menunjukan bahwa peningakan kemampuan menyusun RPP dan respon mahasiswa yang memperoleh pembelajaran menggunakaan model project based learning lebih baik daripada yang memperoleh pembelajaran konvensional. Hasil ini sejalan dengan hasil penelitian Harry \& Purwasih (2015) menyimpulkan bahwa pembelajaran dengan menggunakan pendekatan project based learning dapat meningkatkan keaktifan dan prestasi belajar mahasiswa STKIP Siliwangi pada mata kuliah media pembelajaran.

Berdasarkan pengamatan penulis di lapangan kemampuan menyusun RPP dan respon maahasiswa kelas yang menggunakan pendekatan project based learning lebih baik dikarenakan mahasiswa terbiasa mencari tahu sendiri juga menyelesaikan masalah hasil pemikiran sendiri secara kelompok. Selain itu selama pengumpulan informasi terjadi kegiatan berpikir yang kemudian akan menimbulkan pemahaman yang mendalam dalam belajar dan akan mendorong terjadinya pemusatan perhatian terhadap topik sehingga membuat mahasiswa menggali lebih banyak informasi yang membuat hasil belajar lebih bermutu (Umbara, 2016:144).

Berbeda dengan kelas yang menggunakan pembelajaran biasa karena pada kelas kontrol siswa terbiasa menerima penjelasan dari guru sehingga mahasiswa besar kemungkinan mengalami kesulitan jika tidak mendapat bantuan dari guru. Untuk keaktifan berdiskusi kelompok siswa kelas eksperimen sebagian besar kelompok berdiskusi dengan aktif, sedangkan pada kelas kontrol hanya sebagian kecil kelompok yang berdiskusi dengan aktif dan interaktif.

Selanjutnya untuk mengetahui peningkatan kemampuan mahasiswa dalam menyusun RPP yang telah dicapai dan kualifikasinya digunakan data gain. ternormalisasi yang diformulasikan oleh Hake (1999). Rerata gain ternormalisasi merupakan gambaran peningkatan kemampuan mahasiswa dalam menyusun RPP. Rumus untuk gain ternormalisas adalah : 
$(\mathrm{N}$-gain $)=\frac{\text { skor postes-skor pretes }}{\text { skor maksimal ideal-skor pretes }}$

Vol. 2, No. 2, April 2018, pp. 33-42

Tabel 5. Deskripsi Statistik Kemampuan Menyusun RPP

\begin{tabular}{ccccc}
\hline Kelas & Pretes & \multicolumn{2}{c}{ Postes } & Gain \\
\cline { 2 - 5 } & Mean & Mean & Mean & St.Dev \\
Eks & 6,65 & 16,39 & 0,57 & 0,30 \\
Kont & 6,63 & 13,07 & 0,36 & 0,34 \\
\hline
\end{tabular}

Berdasarkan tabel di atas, kualifikasi rerata gain kelas kontrol sebesar 0,576 dan kelas eksperimen sebesar 0,362, keduanya masuk dalam kategori sedang. Setelah dilakukan uji normalitas dan uji homogenitas terhadap gain pada kedua kelompok data peningkatan kemampuan mahasiswa dalam menyusun RPP menunjukkan hasil bahwa data gain kelas eksperimen yang memperoleh penerapan model pembelajaran project based learning dan kelas kontrol yang memperoleh penerapan model pembelajaran konvensional mempunyai varians yang homogen dan keduanya berasal dari populasi yang berdistribusi normal. Selanjutnya untuk mengetahui signifikansi perbedaan rerata peningkatan kemampuan mahasiswa dalam menyusun RPP kedua kelompok data dilakukan uji perbedaan dua rerata dengan hipotesis sebagai berikut:

$\mathrm{H}_{0}: \mu_{1} \leq \mu_{2}$ (Peningkatan kemampuan mahasiswa dalam menyusun RPP melalui model pembelajaran project based learning tidak lebih baik atau sama dibandingkan dengan peningkatan kemampuan mahasiswa dalam menyusun RPP yang memperoleh penerapan model pembelajaran konvensional)

$\mathrm{H}_{1}: \mu_{1}>\mu_{2}$ (Peningkatan kemampuan mahasiswa dalam menyusun RPP melalui model pembelajaran project based learning lebih baik dibandingkan dengan peningkatan kemampuan mahasiswa dalam menyusun RPP yang memperoleh penerapan model pembelajaran konvensional)

Apabila dirumuskan ke dalam hipotesis statistik adalah sebagai berikut:

$\mathrm{H}_{0}: \mu_{1} \leq \mu_{2}$

$\mathrm{H}_{1}: \mu_{1}>\mu_{2}$

Kriteria pengujiannya yaitu:

Jika $P$-Value $\geq 0.05$. maka $\mathrm{H}_{0}$ diterima.

Jika $P$-Value $<0.05$. maka $\mathrm{H}_{0}$ ditolak

Tabel 6. Hasil Uji Signifikansi Perbedaan Dua Rata-rata Skor Postes Kemampuan Menyusun RPP

\begin{tabular}{|c|}
\hline $\begin{array}{l}\text { Two-sample } \mathrm{T} \text { for postes eksperimen vs postes } \\
\text { kontrol }\end{array}$ \\
\hline 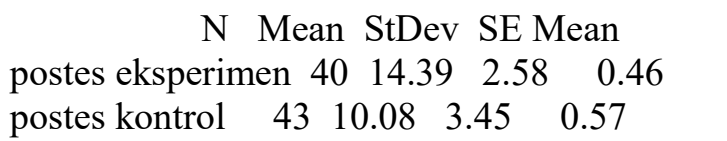 \\
\hline $\begin{array}{l}\text { T-Test of difference }=0(\text { vs not }=): \text { T-Value }= \\
6.17 \text { P-Value }=0.000 \mathrm{DF}=81 \\
\text { Both use Pooled StDev }=3.0578\end{array}$ \\
\hline
\end{tabular}

Dari output data di atas, dapat dilihat bahwa nilai P-Valuenya yaitu 0,000 . Nilai tersebut $<$ 0,05, sehingga $\mathrm{H}_{0}$ ditolak dan $\mathrm{H}_{1}$ diterima, maka terdapat perbedaan rata-rata pada kemampuan 
komunikasi matematis antara siswa di kelas eksperimen dan kelas kontrol setelah pembelajaran dilakukan. Jadi dapat disimpulkan bahwa kemampuan mahasiswa menyusun rpp melalui model pembelajaran project based learning baik daripada kemampuan komunikasi matematis siswa melalui pembelajaran konvensional

Secara keseluruhan kemampuan mahasiswa dalam menyusun RPP meningkat. Hal ini karena penerapan model pembelajaran project based learning melibatkan mahasiswa secara aktif dalam proses pembelajaran. Mahasiswa tidak hanya mempelajari materi yang diberikan, tetapi mereka juga harus mampu memahami dan mempraktekkan seluruh materi yang dipelajari. Hal ini sejalan denngan hasil penelitian dari Izzati (2017:672) bahwa peningkatan kemampuan mahasiswa dalam menyusun RPP yang memperoleh penerapan model pembelajaran project based learning lebih tinggi daripada peningkatan kemampuan mahasiswa dalam menyusun RPP yang memperoleh penerapan model pembelajaran konvensional pada taraf signifikansi 5\%.

Respon mahasiswa selama pembelajaran semakin hari semakin membaik, mahasiswa yang sering bertanya kepada dosen hingga akhirnya berusaha mencari sendiri informasi yang mereka butuhkan melalui memperhatikan sumber informasi yang guru sediakan. Diskusi kelompok semakin baik, hanya saja karena perbedaan kemampuan setiap masing-masing mahasiswa sehingga masih ada beberapa mahasiswa yang pasif dalam kelompoknya. Dalam kegiatan aktivitas-aktivitas menyelesaikan proyek mahasiswa tidak mengalami kesulitan, hanya saja tetap interaksi antar kelompok masih saja kurang, sehingga untuk mendapatkan respon yang baik dosen mengajukkan pertanyaan, pertanyaan kecil yang berhubungan dengan hasil diskusi yang disampaikan. Hasil dari tes tertulis dan angket menggambarkan mahasiswa dalam menyusun RPP senang dan antusias dengan pembelajaran project based learning. Hal ini sejalan dengan penelitian Harry \& Purwasih (2015:135) bahwa prestasi belajar mahasiswa yang memperoleh pembelajaran dengan project based learning lebih baik daripada yang memperoleh pembelajaran dengan metode ekspositori dan keaktifan mahasiswa yang memperoleh pembelajaran dengan project based learning lebih baik daripada yang memperoleh pembelajarandengan metode ekspositori.

\section{Daftar Pustaka}

Izzati, N. (2017). Meningkatkan Kemampuan Mahasiswa Dalam Menyusun Rpp Melalui Penerapan Model Pembelajaran Berbasis Portofolio (Studi Kuasi Eksperimen terhadap Mahasiswa Tadris Matematika. Jurnal Euclid, 4(1), 659-674.

Kurniasih, M.D. (2017).Penerapan Metode Inkuiri Untuk Kemampuan Berpikir Kritis Matematis Mahasiswa Calon Guru. Jurnal Euclid, 4(2), 751-760.

Nurmahmidah. (2017). Penerapan Model Pembelajaran Kooperatif Tipe Teams Games Tournament (Tgt) Pada Pokok Bahasan Peluang Sebagai Upaya Meningkatkan Prestasi Dan Motivasi Belajar Matematika Siswa Kelas X Mia 2 Sma Negeri 1 Sedayu. Jurnal Mercumatika, 1(2,), 139-146.

Putra, H.D., \& Purwasih, R. (2015). Meningkatkan Prestasi Belajar Dan Keaktifan Mahasiswa Melalui Project Based Learning. Jurnal Ilmiah UPT P2M STKIP Siliwangi, 2(2), 128-136.

Putri, I.S., \& Agustyaningrum, N. (2017). Efektivitas Model Pembelajaran Problem Based Instruction Dan Snowball Throwing Ditinjau Dari Hasil Beljar Matematika Siswa Kelas Viii Smpn 51 Batam. Jurnal Mercumatika, 1(2,), 97-103.

Purwasih, R., \& Sariningsih, R. (2017). Pembelajaran Berbasis Masalah untuk Meningkatkan Kemampuan Berpikir Kreatif dan Self-Concept Siswa SMP. Jurnal Didaktik Matematika, $4(1), 15-24$. 
Riduwan. (2007). Skala Pengukuran Variabel-variabel Penelitian. Bandung: Alfabeta.

Ruseffendi, E.T. (2010). Dasar-Dasar Penelitian Pendidikan \& Bidang Non-Eksakta Lainnya. Bandung: Tarsito.

Sariningsih, R., \& Purwasih, R. (2017). Pembelajaran Problem Based Learning Untuk Meningkatkan Kemampuan Pemecahan Masalah Matematis Dan Self Efficacy Mahasiswa Calon Guru. Jurnal JNPM (Jurnal Nasional Pendidikan Matematika), 1(1), 163-177.

Umbara, U. (2016). Implementasi Pendekatan Resource Based Learning terhadap Peningkatan Kemampuan Pemecahan Masalah Matematis Siswa SMP. Jurnal Matematika Ilmiah STKIP Muhammadiyah Kuningan, 2(1), 133-145.

Winkel, W.S. (2004). Psikologi pengajaran. Yogyakarta: Media Abadi. 